
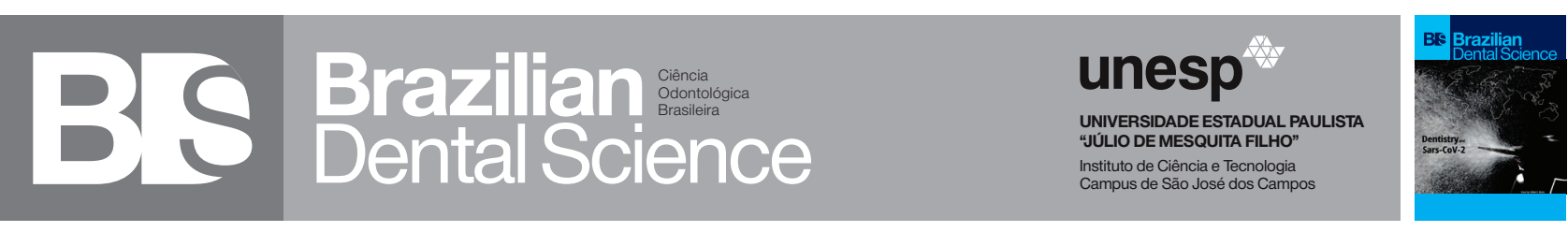

\title{
Understanding SARS CoV-2 biology to win COVID-19 battle
}

\author{
Entendendo a biologia do SARS CoV-2 para vencer a batalha contra a COVID-19
}

Cristiane Yumi KOGA-ITO' ${ }^{1}$, Henrique Toshiaki KOGA-ITO ${ }^{2}$, Aline da Graça SAMPAIO ${ }^{1}$, Mariana Raquel da Cruz VEGIAN ${ }^{1}$

1 - São Paulo State University (UNESP) - Institute of Science and Technology - Department of Environmental Engineering and Oral Biopathology Graduate Course - São José dos Campos - SP - Brazil.

2 - Paulista School of Medicine - Universidade Federal de São Paulo - UNIFESP.

\begin{abstract}
This review highlights the main findings on the biology of SARS CoV-2 and the strategies to combat COVID 19 pandemic. Since the initial outbreak in China on December 2019, the international scientific community joined efforts in an unprecedent public health battle. In late May 2020, 5204508 cases and 337687 deaths have been reported by World Health Organization, with higher number of cases in Europe and Americas. SARS-CoV-2 was described as a novel variant from the coronavirus family and its genome was sequenced within a few months while COVID 19 quickly spread worldwide. The main cell receptor (angiotensin converting enzyme 2) was identified as involved in the invasion of host cells. As a result of the findings from cell biology, immunology and clinical studies, the pathogenesis of the virus started to be understood but it has been not fully elucidated so far. While a massive effort for the development of a vaccine is on course, preventive protocols for infection control have been proposed. Many studies on the discovering of effective therapeutic protocols have been developed, particularly on the redirection of already approved substances, but no gold standard treatment was established until now. An overview on the envisioned socioeconomic and politic impacts suggest that our society will be transformed after COVID 19 pandemia. As a result, deep changes in science, politics, socioeconomic and healthcare priorities shall appear in post-pandemia agenda.
\end{abstract}

\section{KEYWORDS}

COVID 19; Pandemic; SARS-CoV-2; Coronavirus.

\section{RESUMO}

Esta revisão destaca os principais relatos sobre a biologia do SARS CoV-2 e as estratégias para combater a epidemia de COVID 19. Desde o surto inicial na China, em dezembro de 2019, a comunidade científica internacional uniu esforços em uma batalha de saúde pública sem precedentes. No final de maio de 2020, 5.204 .508 casos e 337.687 mortes foram reportadas pela Organização Mundial da Saúde, com maior número de casos na Europa e nas Américas. O SARS-CoV-2 foi descrito como uma nova variante da família coronavírus e seu genoma foi sequenciado em poucos meses, enquanto a COVID 19 se espalhou rapidamente pelo mundo. O receptor celular principal (angiotensin converting enzyme 2) foi identificado como envolvido no processo de invasão às células do hospedeiro. Como resultado das descobertas da biologia celular, imunologia e estudos clínicos, a patogênese do vírus começou a ser entendida mas não está completamente elucidada até o momento. Enquanto um grande esforço para o desenvolvimento da vacina está em curso, protocolos preventivos para o controle de infeção foram propostos. Muitos estudos para o estabelecimento de protocolos terapêuticos efetivos têm sido desenvolvidos, particularmente no reposicionamento de substâncias já aprovadas, porém nenhum tratamento padrão foi estabelecido até o momento. Uma visão geral dos impactos políticos e socioeconômicos previstos sugerem que nossa sociedade será transformada após a pandemia de COVID 19. Como resultado, mudanças profundas nas prioridades da ciência, política, área socioeconômica e saúde deverão surgir na agenda póspandemia.

\section{PALAVRAS-CHAVE}

COVID 19; Pandemia; SARS-CoV-2; Coronavírus. 


\section{Origin and evolution of COVID-19 pandemic}

7 he SARS-CoV-2, causative of the COVID-19

pandemic, was first detected during an initial outbreak in Wuhan, China, on December 2019. Several new cases of pneumonia of unknown etiology triggered the alarm for a possible new virus, similar to the causative viruses of Middle East Respiratory Syndrome (MERS) and Severe Acute Respiratory Syndrome (SARS) [1,2]. The virus was firstly isolated from the airway epithelial cells from infected patients on January 2020 [3] and rapidly spread globally. On March, the World Health Organization announced COVID-19 outbreak as a pandemic [4].

Even though the first cases were detected in China, as well as the first confirmed deaths caused by the virus, on May 2020, a number of countries already have superior number of cases and deaths by COVID-19 than what has been reported in China [5]. In early May, most cases and deaths are currently occurring in Europe and Americas, specially, in the United States of America with 1093 880 cases and 62406 deaths, whilst Brazil stands in second place with 91589 cases and 6329 deaths. In late May, 5204508 cases and 337687 deaths have been reported by World Health Organization [5], with most of deaths registered still in Europe (173 886) and Americas (138 116).

Nevertheless, the numbers may be underestimated, as sub notification rates in the South American countries must be accounted for, due to low testing rates in comparison with countries like South Korea, in which mass testing and contact tracing lead to just over 10 000 cases and 250 deaths within a population of around 51 million people [6]. Countries such as Spain, Italy and the United Kingdom lead the numbers in Europe, but it is important to point out that the UK is presenting a much higher number of new cases than the others and may surpass them in the near future [5].

Although away from mainstream news, the African continent's reality is concerning, with a $47 \%$ increase in COVID-19 cases from April 29 to May 6, considering the health structure, social inequality and poverty problems faced by most African nations and by large parts of their population. These issues can influence in higher transmission and mortality rates in comparison with better structured and equipped health systems [7]. In late May, 77295 cases and 2073 deaths were reported by WHO [5], however, the possibly high sub notification of cases should be considered.

\section{Understanding SARS-CoV-2 biology and pathogenesis}

The SARS-CoV-2 is a novel variant from the coronavirus family. Phylogenetic studies discovered the new SARS-CoV-2 as a member of the Betacoronavirus genus and the Sarbecovirus subgenus [1]. The SARS$\mathrm{CoV}-2$ is an enveloped, single-stranded RNA and positive-sense virus, as seen in the other members of the coronavirus family. Although from the same family, the coronaviruses are distinct among themselves and present different characteristics, such as natural hosts and viral structures [1]. SARS-CoV-2 is described as seventh member of the coronavirus family to be able to cause human infections [3].

From genetic analyses, researchers have found relations between SARS-CoV-2 and SARS-CoV, the variant from the SARS outbreak in 2002. Also, high similarity (88\%) between SARS-CoV-2 and two coronavirus found in bats (SL-CoVZC45 and bat-SL-CoVZXC21) were detected [8]. However, there is no evidence of direct transmission between bats and humans so far. Hence, there is the suggestion that the natural reservoir of SARS-CoV-2 might be bats. Some similarities between SARS-CoV-2 and pangolin coronavirus suggest that the pangolin might be the intermediate host $[1,9]$.

The envelope spike protein (S), structure responsible for receptor binding and cell membrane fusion, is a key factor for the 
transmissibility of the virus. The main cellular receptor is the Angiotensin Converting Enzyme 2 (ACE2) [8], as is observed for SARS-CoV, suggesting that they might have similar life cycles $[1,3]$. A major difference is the affinity between the $S$ protein and ACE2 for each virus, given that the affinity for ACE2 for the $S$ protein from SARS-CoV-2 is 10 to 20 times greater than the affinity of the $S$ protein in SARS-CoV. These findings suggest that this greater affinity might make it easier for the SARS-CoV-2 to infect patients [1]. It was noticed that higher levels of ACE2 expression were related to infection susceptibility by SARS-CoV-2, as observed in upper and lower respiratory tract, heart, kidney and gastrointestinal tracts $[10,11]$. These evidences help explain the secondary viremia observed in some cases, in which other systems apart from the respiratory systems were compromised by the viral infection [10,11]. In severe cases, multiple organs such as spleen, kidney, liver, lymph nodes and brain can be also affected [12]. The exact mechanism of virus spreading to these organs are still unknown [12].

Apart from that, studies concerning both SARS-CoV and SARS-CoV-2 discovered that, for the virus to enter the host cell, the $S$ protein requires cellular proteases such as TMPRSS2, a key factor of viral spread, and $\mathrm{CatB} / \mathrm{L}$, observed as secondary in the process. These proteases have a priming action over the $\mathrm{S}$ protein. This process makes the fusion of viral membrane and cellular membrane possible, an essential part of viral spread $[13,14]$. Further studies exploring the relation between TMPRSS2 and SARS-CoV-2 infection susceptibility provided some experimental evidences reinforcing this relation. By using engineered VeroE6/TMPRSS2 cells, expressing TMPRSS2 protease 10-fold higher than control VeroE6 cells, the results showed that the VeroE6/TMPRSS2 cells were more susceptible to infection by SARS-CoV-2, when compared to control VeroE6 cells. This information helps sustain that TMPRSS2 does have an important function in the process of host cell infection by SARS-CoV-2 [15]. Another difference between SARS-CoV-2 and other coronaviruses is that SARS-CoV-2 does not use receptors such as aminopeptidase-N and dipeptidyl peptidase 4(DPP4), which are used by other coronaviruses [1].

Clinically, infection by SARS-CoV-2 usually causes a mild illness with good prognosis [16]. It is estimated that $80 \%$ of the infected individuals will develop the mild form of the disease, restricted to upper and conducting airways [17]. However, in approximately $5 \%$ of the patients, severe lung injury and systemic organ failure occur [18]. Despite of the efforts of the global scientific community, the pathogenesis of SARSCoV-2 infection in humans has not been fully elucidated [12], although some hypotheses have been raised.

The hypothetical pathogenesis of COVID-19 proposed by Lin et al. [16] is based on the immunological phenomena occurring during the SARS-CoV-2 infection. The authors suggested that the number of lymphocytes ( $\mathrm{T}$ and $\mathrm{B}$ cells) decreases as the disease progress and, in parallel, inflammatory cytokines (i.e. IL-6) and D-Dimer levels increase significantly in patients with severe conditions, possibly leading to the formation of inflammatory factors storms. Mason et al. [19] hypothesized the pathogenesis of COVID-19 from a cell biology perspective and suggested that mild disease affects the conducting airways and when the virus affects the gas exchange portion of the lung, the severe form of the disease occurs.

More focused on the clinical approach, Li et al. [12] hypothesized that the viral sepsis is a critical point to the mechanism of the disease. According to these authors, this hypothesis is based on clinical occurrences that lead to the diagnosis of sepsis and septic shock with SARS-CoV-2 infection as the unique cause.

Despite of being very useful for understanding the pathogenesis of the disease, studies on the pathogenesis of SARS-CoV-2 
using experimental induction are scarce so far. Recently, Sia et al. [20] reported the successful induction of SARS-CoV-2 infection in golden hamsters. The authors were able to transmit the virus from experimentally inoculated animals to naïve ones by direct contact and aerosols. Interestingly, all diseased animals recovered from infection and neutralizing antibodies were detected.

Tools to combat COVID-19 pandemics: Preventive and Therapeutic protocols

\section{Preventive protocols}

\section{Environmental infection control}

Considering the transmission route of SARS-CoV-2, the adoption of routine protocols for controlling the virus spreading is essential. Viruses are capable of remaining suspended, for several hours, in moist droplets in the air, after coughing or breathing and being transported by air currents over small distances $(1 \mathrm{~m})$ until they fall to the ground. Experimental models suggest that transmission between individuals can occur over a distance of more than two meters [21]. A study with SARS-CoV-2 showed persistent presence of the virus in the air for 3 hours [22]. Ren et al. [23] reported the presence of SARS-CoV-2 in poorly ventilated environments for approximately $30 \mathrm{~min}$.

It has been previously proved that transmission of viruses occurs frequently during health care clinical procedures, due to the release of oral fluids and nasal droplets caused by coughing, sneezing and conversation [24]. For this reason, barriers against droplets and proper disinfection of surfaces are important to protect health professionals and patients [25]. Adequate environmental infection control procedures should be also adopted, such as increased frequency and quality disinfection and adequate ventilation $[26,27]$.

Methods of air quality control and inactivation of aerosols can contribute to inhibit the spread of the virus in the environment and are of great interest in this moment of global threat by COVID-19. In hospital environments, negative pressure rooms are recommended to control the spread of aerial infections [28]. No SARS-CoV-2 was detected in hospital wards where indoor air was treated by an air disinfector based on plasma technology in a Chinese hospital [29]. Other methods have been proposed for the airborne transmission control of other viruses, such as UV-C [30] have been proposed for SARS-CoV-2, however no studies on the subject have been published so far.

The contamination of surfaces by SARSCoV-2 is another critical point. The virus remained viable on plastic $(72 \mathrm{~h})$, stainless steel (48h), copper (4h) and cardboard surfaces (24h) (Doremalen et al., 2020). Kampf et al. [31] reported that $0.1 \%$ sodium hypochlorite and ethanol solutions (62 and $71 \%$ ) were able to eliminate SARS-CoV-2 after 1 min exposure. pandemics

Health care settings operation during

It is noteworthy that some health professionals are under higher occupational risk during COVID-19 pandemics, such as the dentists [32]. During dental care procedures, high generation of aerosols and droplets of saliva, blood, microorganisms and other debris can occur due to the use of rotatory dental and surgical instruments $[26,33]$. Despite of this, it seems that this risk has been sometimes underestimated. A survey conducted worldwide revealed that only $43.8 \%$ of dentists alerted their staff to the WHO Guidelines on preventive care for COVID-19 [34].

CDC recommended that dental settings should prioritize urgent and emergency visits [33]. Pre-clinical screening methods are considered an effective approach to prevent the spread of the virus in the clinical practice $[35,36]$ and help the professionals to detect emergency situations. Alharbi et al. [37] proposed guidelines to dental care of patients during and after the COVID-19 pandemic. 
The method includes pre-examination and initial screening based on symptoms, clinical history and current stage of the patient, recent contacts with people infected by the virus, travel to places with disease alert, the need for urgent treatment, and the risks and benefits of the procedure. According to these parameters, patients were classified into asymptomatic groups without suspicion and unconfirmed, symptomatic and suspect, not confirmed in the examination, confirmed and stable with a mild situation, without hospitalization or oxygen therapy, confirmed and unstable in a critical or severe situation, confirmed and recovered on examination, and asymptomatic for 30 days. Besides, the procedures were categorized by the degree of invasiveness and urgency (emergency, urgent with minimal invasiveness and no aerosol production, urgent with high invasiveness and aerosol production, and selective non-urgent).

Once the emergency is detected, the health professionals should adopt strict infection control measures. On February 2020, the World Health Organization (WHO) released a guideline for the universal care to combat COVID-19, which includes body temperature measurement, masks use, hand washing, social distance and follow up of signs and symptoms of the disease. It is important to highlight that screening the absence of symptoms is inadequate to prevent the spread of the disease, as SARS-CoV-2 has also been already detected in asymptomatic health professionals [38].

Hand hygiene and the use of personal protective equipment (PPE) is necessary for medical staff. As standard prevention strategies, it is recommended to use N95 filtering facepiece respirator, long-sleeved water-resistant gowns, disposable gloves, and face shield [33,39]. The PPE acts as a containment barrier against viral droplets [21].

Oral care protocol should be focused on reduction of viral spread and control of cross-infection pathways [37]. This protocol included the adoption of a minimally invasive performance with low aerosol production, limited use of intraoral radiographs, use of disposable instruments and devices, and use of rubber dam [37]. Meng et al. [26] also suggested use of absorbable sutures, slow rinse procedure and use of saliva ejector. Additionally, the 4-handed technique can contribute to infection control [26]. The use of mouthwashes previously to the procedure was also recommended [27,37]. Radiographic examinations could be performed with computed tomography (CT) with a conical beam and panoramic radiography [26].

Another widely adopted strategy is the use of telemedicine and teledentistry. In fact, health professionals, including dentists, during an outbreak of COVID-19 in Wuhan, provided assistance using online platforms and classified the methodology as a useful protection measure [26]. Cell phone applications that allow the sending of instant messages, photos and video helped significantly [40], mainly in palliative care, follow up of clinical progress [41] and distance care [42]. Caprioglio et al. [43] reported that the virtual assistance to patients undergoing orthodontic treatment was effective to solve or minimize non-emergency problems.

\section{Vaccines development}

Amidst the concerningly rising number of infected and death toll, researchers and labs from around the world are rushing to develop a SARS-CoV-2 vaccine. In order to achieve that, three main strategies are being explored: whole virus, subunit and nucleic acid vaccines [44].

The whole virus vaccine is the most traditional approach, containing liveattenuated or inactive viruses, with advantages such as their inherent immunogenicity and capacity of stimulating toll-like receptors (TLRs). Nevertheless, these vaccines require more extensive safety testing, especially, considering that some findings pointed out an increase in infectivity after immunization with 
active and inactive whole SARS coronavirus vaccines $[44,45]$.

In addition to that, research in subunit vaccines is also under development. In this case, the aforementioned Spike (S) Protein is the main target of $\mathrm{RBD}$ (receptor-binding domain)-based vaccines for SARS-CoV-2, aiming to stop the virus from binding to the ACE2 receptor [44]. The most recent finding amongst the three are nucleic acid vaccines, in which viral RNA is used to express encoded viral proteins, inducing both cellular and humoral responses to the protein. It is important to point out that, even though it may have a lot of potential, this technology has not yet had applications on humans [44].

In order to have an impact in the current Covid-19 pandemic, the vaccine must be backed with organized international cooperation, aiming to provide speed and universal access, as well as manufacture and distribution at global scale [45]. Even so, international organizations, such as the WHO, have not taken concrete actions yet to assure equitable distribution or to coordinate the production of vaccine [46]. Another golden question is "When?", to which early 2021 is a highly optimistic forecast, considering the fact that most vaccines will take up to 10 years to be developed. Nevertheless, unprecedented effort and technology are being put into the Covid-19 research, which can hopefully trim down the normal development time [46].

\section{Therapeutic protocols}

In the first months of 2020, several researchers and medical teams started investigations on therapeutic protocols that could be used to treat COVID-19, mainly with the redirection of already approved substances.

Protocols for antiviral treatments were published in March 2020 by the National Health Commission of China, in 7th edition of Diagnosis and Treatment Protocol for Novel Coronavirus Pneumonia, with guidelines for the use of lopinavir/ritonavir, ribavirin and arbidol, in addition to phosphate chloroquine and interferon- $\alpha$ (IFN- $\alpha$ ) [47].

Most recently, the US Food and Drug Administration issued an emergency use authorization for the administration of antiviral remdesivir in critically diagnosed and hospitalized adults and children [48], followed by authorization from the Japanese Ministry of Health, Labor and Welfare (MHLW). The two recommendations were based on a clinical trials carried out in several countries, which is now in phase III and is supported by Gilead Sciences (NCT04292899).

The antiviral lopinavir associated with ritonavir, a protease inhibitor used against human immunodeficiency virus (HIV), was selected for a recent controlled and randomized clinical trial in China. This trial included 99 hospitalized adults with COVID-19 and was carried out for a period of 14 days [49]. The authors concluded, however, that the treatment had no clinical benefits. Despite this, other studies, using antivirals in association with ribavirin and IFN-[ [50] and with umifenovir [51], have found decreased viral load compared to treatment with lopinavir/ritonavir only. The authors also reported clinical improvement and decreased hospitalization with the addition of ribavirin and IFN-[, when treatment was administered within 7 days after the onset of symptoms.

Remdesivir is an antiviral approved as an inhibitor of HIV reverse transcriptase and has been tested against SARS-CoV, MERS-CoV and Ebola viruses [52]. It was suggested as a therapeutic potential against SARS-CoV-2 based on results from molecular docking and in vitro studies with bronchial epithelial cells and Vero cells E6 [53,54,55]. However, until now, clinical studies conducted with COVID-19 critically ill patients have not shown significant clinical or antiviral effects [56]. In addition, adverse effects were observed in 32 of 53 patients and mortality overall was 13\% [57].

Favipiravir, another antiviral already 
approved for the treatment of influenza A, B and C in Japan, which can effectively inhibit the RNA-dependent RNA polymerase of RNA viruses [52], demonstrated antiviral effects against SARS-CoV -2 in vitro with low cytotoxicity [55]. Clinical studies are being conducted with this antiviral in the treatment of COVID-19 in Italy (NCT04336904), and in China, in combination with interferon- $\alpha$

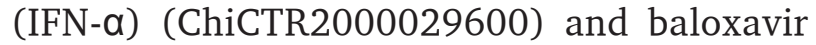
marboxil (ChiCTR2000029544).

Another compound under investigations on its antiviral effect is the chloroquine. It is composed of 4-aminoquinoline, synthesized specifically for antimalarial treatments. It is believed that it can act by altering the lysosomal $\mathrm{pH}$, preventing the release of the viral genetic material inside the cell and decreasing the capacity for its replication [58]. In vitro studies have demonstrated chloroquine antiviral activity against SARSCoV-2 after infection of Vero cells, in different concentrations [55,59].

The hydroxychloroquine, a derivative of chloroquine with lower toxicity [58], is widely used for the treatment of autoimmune diseases. This compound inhibited SARSCoV-2 in vitro, with better antiviral effects when compared to chloroquine $[59,60]$. A clinical study conducted in China with 62 patients divided into control (standard treatment with other drugs) and treated group (hydroxychloroquine), described improvement in the COVID-19 symptoms [61]. The authors concluded that the potential of the drug has been partially confirmed, but highlighted the reduced number of treated patients. Preliminary results from a study in France with 20 patients, described that the treatment with hydroxychloroquine was efficient in removing the viral transport of SARS-CoV-2, and suggested a synergistic effect of the combination with azithromycin [62]. However, in a more recent clinical trial in the United States, 811 COVID-19 patients were treated with hydroxychloroquine associated to azithromycin and the authors reported that, although data was not enough to rule out benefit or harm resulting from treatment, the drug was not associated with clinical improvement [63]. In late May, Mehra et al. [64] reported the results of a large observational study with 96032 severe cases of the disease, analyzing the effects of chloroquine or hydroxychloroquine associated or not with a macrolide. Also, in this study, no clinical benefits were registered. Further investigations are underway in the United States for the prevention of infection in healthcare professionals (NCT04333225) and treatment of patients (NCT04353271), with different doses of hydroxychloroquine and association with azithromycin (NCT04363203). In Italy, the association with azithromycin and probiotics (NCT04368351) is under evaluation.

The evidences that increased plasma concentrations of inflammatory cytokines may led to pulmonary complications in patients with COVID-19 [65], supported the proposal of therapeutic protocols using anti-inflammatory drugs as possible agents or adjuvants to treat the disease. Baricitinib is originally used as an anti-rheumatic and inhibits the protein AAK1. This protein regulates endocytosis and can interfere on the process of entry of the virus into the cell [66]. A pilot study in Italy with 12 patients treated with lopinavir/ ritonavir-associated baricitinib, reported that the clinical and laboratory parameters significantly improved and most of the patients had negative nasal/oral detection of SARS-CoV-2 after treatment [67].

Tocilizumab, an interleukin-6 (IL6) receptor blocking antibody, with antirheumatic potential, was also investigated for therapeutic protocols. Cytokine IL- 6 is produced by $\mathrm{T}$ lymphocytes and macrophages and binds to its receptor on target cells, stimulating inflammatory responses and has been found in high concentrations in patients with COVID-19 [68,69]. The first use of Tocilizumab for the treatment of COVID-19 was described in a case report of a patient 
with multiple myeloma, who had gradual improvement in the clinical conditions after administration of the compound [70]. Clinical improvement was also observed after treatment with tocilizumab in most of 21 patients with severe and critical COVID-19, further suggesting that early treatment with the drug has the potential to reduce the evolution of symptoms. However, due to the limitations of the study, the authors suggested that more controlled studies are still needed [69]. Further clinical trials are underway in Italy (NCT04315480) and France (NCT04331808).

The use of convalescent plasma from patients recovered from COVID-19 was another therapeutic intervention suggested in recent months. The administration of passive antibodies, found in human convalescent sera, aims to provide immediate immunity in individuals with early symptoms and prevent disease in those exposed to the virus [71]. Convalescent plasma have been tested in clinical trials in China with 10 COVID-19 patients in severe conditions [72]. The authors observed improvement in clinical symptoms and reduction in viral RNA after transfusion, however, they did not rule out the possibility of the contribution of antivirals used in the initial treatment. Conversely, in another study with 5 critically ill patients, it was mentioned that the virus was still detectable after treatment with antivirals for 10 days, but the same did not occur after treatment with convalescent plasma [73].

\section{Overview on the impacts of COVID-19 pandemics and Post-epidemics agenda}

In some degree, the whole world is suffering from the impacts of this multifaceted pandemic, due to its various aspects concerning health care, economy and politics [5].

It is consensual that global economy will face recession in the near future due to the effects of the COVID-19 pandemic. Nevertheless, there is a number of known strategies to deal with the economical aspect of the crisis, a scenario similar to the 2008 recession and recuperation process [74,75]. One common strategy used to fight off recession are austerity measures, as applied in countries like Spain, Italy and Greece after 2008. In general lines, this strategy consists in governments seeking to minimize its overall spending, which basically means a bigger slice of taxes being used to fix the macroeconomic crisis in order to induce economic recovery and employment rates growth. However, it also means that public healthcare, social protection and other mechanisms might go underfunded, which can amplify socioeconomic disparities and compromise healthcare, education and generalsafety of sociallyvulnerable populations $[74,76,77]$. Another option is economic stimulation, in which social protection is a priority, nevertheless this strategy relies on massive reserves or credit, therefore imposing a big obstacle to its implantation during and after the pandemic for most countries $[74,75]$. Another aspect to be considered is how the globalized economy can be affected by the impacts on the production chains, as different parts of one product might be made in different parts of the world. This can affect the economy reopening due to other countries that are still in quarantine [74,78]. This is another obstacle to economic recovery that needs to be accounted for in each country's reality.

Approaching the individual economy during the pandemic, it is important to highlight the different impacts of social distancing and quarantine on people with distinct socioeconomic realities. Considering that there is workforce with healthcare and income security, but also workforce in informal employment and without any healthcare or social protection, the results of having to stay at home might stop people from actually being able to do it, not due to widespread boredom, but in order to provide immediate survival for them and their families [74,79]. Which is why some countries, like the USA, France and many others, are drawing packages to 
avoid healthcare stress and expansion of other emerging social problems $[74,80]$.

The political implications of the pandemics are diverse and have not yet fully developed. Nevertheless, the tension between governments due to the COVID-19 pandemic is noticeable, as was seen when politics blamed China for the virus or named SARS-CoV-2 as the "Chinese Virus" [74]. These attacks bring xenophobia into a crisis that inflicts damage to the whole world and a non-intentional problem, contrary to some opinions on an "engineered coronavirus" without any scientific evidence [74,81].

Apart from that, it is still common to see misinformation and politization of scientific studies and information, specially, during a global pandemic, in which everyone is desperate for an instant solution. One recent case was when early studies about chloroquine in the treatment of COVID-19 were marketed as an approved and certain cure on social medias, spilling over to political discussions over the application and efficiency of the medication, suggesting that, with the drug, the quarantine was pointless [81]. It was not rare to see "pro-chloroquine" politicians in the headlines. It is crucial to point out that no study about Chloroquine and SARS-CoV-2 has solidly proved the efficiency and safety of the drug against the novel coronavirus in humans $[63,64]$. This kind of legitimacy supporting these ideas is obtained through the high visibility of millions of followers, while scientists must conquer this validation through experimentation following the scientific method and peer examination. Cases like that highlights the lack of scientific education throughout most of the general public, apart from the fact that the misrepresentation of science is recurrently used to obtain a political advantage either ignoring or misusing scientific articles and studies, damaging both politics and the scientific community severely [81].

During the Covid-19 pandemic and due to its severity, other problems were set aside, social inequality becomes more evident and the already collapsing scenario gets more dramatic. One of this issues are the refugees, more precisely 25,9 million of them, according to United Nations High Commissioner for Refugees [82]. This means that, apart from the risks concerning COVID-19 in the crowded refugee camps, other deadly diseases, such as malaria, polio and many others, are set to hit even harder following the worsening of already poor sanitary conditions inside the camps. This is alarming as it may be another humanitarian crisis in the making, apart from the situations imposing the refugee state to many human beings [83]. The situation of African continent is also concerning as COVID-19 pandemic is a massive challenge for most of the African nations affected by high social inequality and poverty [7].

In brief, dramatic transformation in our society are expected in post-pandemic. The world as a whole will be poorer due to global economy recession and there will be an increase in socioeconomic inequalities. The way we used to live, to buy, to teach and learn, to work on healthcare settings, to interact with people will change significantly. Besides of the unmeasurable losses, the pandemia encourages organized international cooperation to combat SARS-CoV-2 and avoid future similar occurrences.

\section{REFERENCES}

1. HeF,Deng Y,LiW. Coronavirus disease 2019: What we know? [published online ahead of print,2020 Mar 14].J Med Virol.2020;10.1002/jmv.25766. doi:10.1002/ jmv.25766

2. Rothan HA, Byrareddy SN. The epidemiology and pathogenesis of coronavirus disease (COVID-19) outbreak. J Autoimmun. 2020;109:102433. doi:101016/j. jaut.2020.102433

3. Wang H,LiX1Li T,Zhang S, Wang L, WuX, Liu J. The genetic sequence, origin, and diagnosis of SARS-CoV-2. Eur J Clin Microbiol Infect Dis. 2020;1-7. doi:10.1007/s10096-020-03899-4

4. World Health Organization WHO [Internet]. [cited 2020 May 25]. WHO announces COVID-19 outbreak a pandemic Available from: http://www.euro. who.int/en/health-topics/health-emergencies/coronavirus-covid-19/news/ news/2020/3/who-announces-covid-19-outbreak-a-pandemic.

5. World Health Organization WHO [Internet]. [cited 2020 May 4]. Coronavirus disease (COVID-19). Situation Report-104. Available from: https:/www.who. int/docs/default-source/coronaviruse/situation-reports/20200503-covid-19sitrep-104.pdf?sfvrsn=53328f46_2. 
6. Salathé M, Althaus CL, Neher R, Stringhini S, HodcroftE, Fellay J et al. COVID-19 epidemic in Switzerland: on the importance of testing, contact tracing and isolation. Swiss Med Wkly. 2020;150:w20225. Published 2020 Mar 19. doi:10.4414/smw.2020.20225

7. WHO African Region. External Situation Report 9 [Internet]. [cited 2020 May 6]. Available from:https://apps.who.int/iris/bitstream/handle/10665/331989/ SITREP_COVID-19_WHOAFRO_20200506-eng.pdf.

8. LuR, Zhao X, LiJ, Niu P, Yang B, Wu H etal. Genomic characterisation and epidemiology of 2019 novel coronavirus: implications for virus origins and receptor binding. Lancet. 395(10224):565-574. doi:101016/S01406736(20)30251-8.

9. Caldaria A, Conforti C, Meo ND, Dianzani C, Jafferany M, Lotti T etal. COVID-19 and SARS: Differences and similarities [published online ahead of print, 2020 Apr 11]. Dermatol Ther.2020;e13395. doi:10.1111/dth.13395

10. Petrosillo N, Viceconte G, Ergonul 0, Ippolito G, Petersen E. COVID-19, SARS and MERS: are they closely related? Clin Microbiol Infect. 2020;26(6):729-34. doi:10.1016/..cmi.2020.03.026

11. Cao W,Li T. COVID-19: towards understanding of pathogenesis. Cell Res. 2020;30(5):367-9. doi:10.1038/s41422-020-0327-4

12. LiH, Liu L, Zhang D, Xu J, Dai H, Tang N et al. SARS-CoV-2 and viral sepsis: observations and hypotheses. Lancet. 2020;395(10235):1517-20. doi:10.1016/ S0140-6736(20)30920-X.

13. Hoffman M, Kleine-Weber H, Schroeder S, Krüger N, Herrler T,Erichsen Set al. entry SARS-CoV-2 Cell depends on ACE2 and TMPRSS2 and is blocked by a clinically proven protease inhibitor.Cell Press. 2020;81(2):271-280.e8. doi: 10.1016/j.cell.2020.02.052

14. Simmons G, Zmora P, Gierer S, Heurich A, Pöhlmann S. Proteolytic activation of the SARS-coronavirus spike protein: Cutting enzymes at the cutting edge of antiviral research. Antiviral Res.2013;100(3):605-14. doi:10.1016/] antiviral.2013.09.028.

15. Matsuyama S, Nao N, Shirato K, Kawase M, Saito S, Takayama letal Enhanced isolation of SARS-CoV-2 by TMPRSS2-expressing cells. PNAS. 2020;117(13):7001-3. doi: 10.1073/pnas.2002589117.

16. Lin L, Lianfeng L, Wei C, Taisheng L. Hypothesis for potential pathogenesis of SARS-CoV-2 infection-a review of immune changes in patients with viral pneumonia. Emerg Microbes Infect 2020 Dec;9(1):727-32 doi: 10.1080/22221751.2020.1746199

17. WuZ, McGoogan JM. Characteristics of and important lessons from the coronavirus disease 2019 (COVID-19) outbreak in China: summary of a report of 72314 cases from the Chinese Center for Disease Control and Prevention. JAMA. 2020; epub. doi:10.1001/jama.2020.2648.

18. Guan WJ,Ni ZY, Hu Y, Liang W, Ou C, He J et al. Clinical characteristics of coronavirus disease 2019 in China. NEngl J Med 2020;382:1708-20. doi: 10.1056/NEJMoa2002032

19. MasonRJ. Pathogenesis of COVID-19 from a cell biology perspective. Eur Respir J. 2020;55(4):2000607. Published 2020 Apr 16. doi:101183/13993003.00607-2020.

20. Sia SF, Yan L, Chin AWH, Fung K, Choy K, Wong AYL etal. Pathogenesis and transmission of SARS-CoV-2 in golden hamsters [published online ahead of print, 2020 May 14]. Nature. 2020;10.1038/s41586-020-2342-5. doi:10.1038/ s41586-020-2342-5.

21. Setti L, Passarini F,Gennaro G, Barbieri P,Perrone MG, Borelli M etal. Airborne transmission route of COVID-19: why 2 Meters/ 6 feet of inter-personal distance could not be enough. Int J Environ Res Public Health. 2020;17(8):2932 doi:10.3390/ijerph17082932

22. Doremalen N, Bushmaker T, Morris DH, Holbrook MG, Gamble A, Williamson BN et al. Aerosol and surface stability of SARS-CoV-2 as compared with SARSCoV-1. NEngl J Med. 2020 Apr 16;382(16):1564-7. doi: 10.1056/NEJMc2004973.
23. Ren S, Wang W, Hao Y,Zhang H, Wang Z, Chen Y etal. Stability and infectivity of coronaviruses in inanimate environments. World J Clin Cases. 2020; 8(8):1391-9. doi:10.12998/wjcc.v8.18.1391.

24. Kohn WG, Collins AS, Cleveland JL, Harte JA, Eklund KJ, Malvitz DM. Guidelines for infection control in dental health-care settings--2003. MMWR Recomm Rep. 2003;52(RR-17):1-61.

25. Adams J, Walls RM. Supporting the Health Care Workforce During the COVID-19 Global Epidemic. JAMA. 2020;323(15):1439-1440. doi:10.1001/ jama.2020.3972.

26. Meng L, Hua F,Bian Z. Coronavirus Disease 2019 (COVID-19): Emerging and Future Challenges for Dental and Oral Medicine. J Dent Res. 2020;99(5):481-7. doi:10.1177/0022034520914246

27. Dexter F,Parra MC, Brown JR, Loftus RW. Perioperative COVID-19 Defense: An Evidence-Based approach for optimization of infection control and operating room management. Anesth Analg. 2020 Mar 26;10:1213/ ANE.0000000000004829. doi:10.1213/ANE.0000000000004829.

28. Zimmermann M,NkenkeE. Approaches to the management of patients in oral and maxillofacial surgery during COVID-19 pandemic. J Craniomaxillofac Surg. 2020 May;48(5):521-6. doi:10.1016/.j.cms.2020.03.011.

29. Wang J, Feng H, Zhang S, NiZ, Ni L, Chen Y et al. SARS-CoV-2RNA detection of hospital isolation wards hygiene monitoring during the Coronavirus Disease 2019 outbreak in a Chinese hospital. Int J Infect Dis. 2020;94:103-6. do: 10.1016/.j.jid.2020.04.024.

30. Bedell K, Buchaklian AH, Perlman S. Efficacy of an automated multiple emitter whole-room ultraviolet-c disinfection system against coronaviruses MHV and MERS-CoV.Infect Control Hosp Epidemiol. 2016;37(5):598-9. doi:10.1017/ ice.2015.348.

31. Kampf G, TodtD,Pfaender S, SteinmannE. Persistence of coronaviruses on inanimate surfaces and its inactivation with biocidal agents. JHosp Infect. 2020 Mar;104(3):246-51. doi: 10.1016/j.jhin.2020.01.022.

32. Gamio L. The Workers who face the greatest coronavirus risk [Internet]. The New York Times [cited 2020 may 12]. Available from:https://www.nytimes. com/interactive/2020/03/15/business/economy/coronavirus-worker-risk.ht ml?action=click\&module=TopUStories\&pgtype=Homepage

33. Centers for Disease Control and Prevention (CDC) [Internet]. Interim Guidance for Emergency Medical Services (EMS) Systems and 911 Public Safety Answering Points (PSAPs) for COVID-19 in the United States. [cited 2020 May 14]. Available from:https:/www.cdc.gov/coronavirus/2019-ncov/hcp/ guidance-for-ems.html.

34. Kamate SK, Sharma S, Thakar S, Srivastava D, Sengupta K, Hadi AJ et al. Assessing Knowledge, Attitudes and Practices of dental practitioners regarding the COVID-19 pandemic: a multinational study. Dent Med Probl. 2020;57(1):11-7.doi:10.17219/dmp/119743.

35. Xiong F, Tang H, Liu L, Tu C, Tian J, LeiC etal. Clinical characteristics of and medical interventions for COVID-19 in hemodialysis Patients in Wuhan, China.J Am Soc Nephrol. 2020 May 8;ASN.2020030354. doi:10.1681/ASN.2020030354.

36. Liu J, Liao X, Qian S, Yuan J, Wang F, Liu Y et al. Community transmission of severe acute respiratory syndrome coronavirus 2, Shenzhen, China, 2020. Emerg InfectDis. 2020 Jun;26(6):1320-3. doi:10.3201/eid2606.200239.

37. Alharbi A,Alharbi S, Alquaidi S. Guidelines for dental vare provision during the COVID-19 Pandemic. Saudi Dent J. 2020 May; 32(4): 181-6. doi:10.1016/j. sdenti.2020.04.001.

38. Arons MM, Hatfield KM, Reddy SC, Kimball A, James A, James A etal. Presymptomatic SARS-CoV-2 infections and transmission in a skilled nursing facility.N Engl J Med 2020; 382:2081-2090. doil: 10.1056/NEJMoa2008457.

39. ECDC (European Centre for Disease Prevention and Control) technical report. [Internet]. Personal protective equipment(PPE) needs in healthcare settings for the care of patients with suspected or confirmed novel coronavirus (2019nCoV).[cited 2020 May 25]. Available at:https://www.ecdc.europa.eu/sites/ 
default/files/documents/novel-coronavirus-personal-protective-equipmentneeds-healthcare-settings.pdf.

40. GulactiU, Lok U, Hatipoglu S, Polat H. An analysis of WhatsApp usage for communication between consulting and emergency physicians. J Med Syst. 2016 Jun;40(6):130. doi:10.1007/s10916-016-0483-8.

41. Mercadante S, Adile C, Ferrera P,GiulianaF, Terruso L, Piccione T. Palliative Care in the Time of COVID-19 [published online ahead of print,2020 May 4]. JPain Symptom Manage. 2020;S0885-3924(20)30245-1. doi:10.1016/j. jpainsymman.2020.04.025.

42. Rastogi S, Singh N, Pandey P.On the brighter side of COVID-19 induced lockdown: devising the collateral methods to provide Ayurveda consultation during impasse. J Ayurveda Integr Med. 2020 May 8. doi: 10.1016/j. jaim.2020.05.001.

43. Caprioglio A, Pizzeti, GB, Zecca, PA, Fastuca, R, Maino G, Nanda, R. Management of orthodontic emergencies during 2019-NCOV. Progress Orthod. 21:10.2020. doi: 10.1186/s40510-020-00310-y.

44. Chen W, StrychU,Hotez PJ, Bottazzi ME. The SARS-CoV-2 Vaccine Pipeline: an Overview. Curr Trop Med Rep. 2020;3;1-4. doi: 101007/s40475-020-00201-6.

45. Le TT,AndreadakisZ, Kumar A, Román RG, Tollefsen S, Saville M, etal. The COVID-19 vaccine development landscape. Nat Rev Drug Discov. 2020 May;19(5):305-6. doi: 10.1038/d41573-020-00073-5.

46. Khamsi R. If a coronavirus vaccine arrives, can the world make enough? Nature. 2020;580(7805):578-80. doi:10.1038/d41586-020-01063-8.

47. (Released by National Health Commission \& National Administration of Traditional Chinese Medicine on March 3,2020). Diagnosis and Treatment Protocol for Novel Coronavirus Pneumonia (Trial Version 7). Chin Med J (Engl). 2020;133(9):1087-95. doi:10.1097/CM9.0000000000000819.

48. U.S. Food \& Drug Administration. Coronavirus (COVID-19) Update: FDA Issues first Emergency Use Authorization for Point of Care Diagnostic. Press Announc. [Internet]. 2020;1-2. Available from: https://www.fda.gov/newsevents/press-announcements/coronavirus-covid-19-update-fda-issues-firstemergency-use-authorization-point-care-diagnostic

49. Cao B, Wang Y, Wen D, Liu W, Wang J, Fan G, et al. A Trial of Lopinavir-Ritonavir in Adults Hospitalized with Severe Covid-19. NEngl J Med. 2020;382(19):178799. doi:101056/NEJMoa2001282

50. Huang M, Tang T, Pang P,Li M, Ma R, Lu J, etal. Treating COVID-19 with chloroquine. J. J Mol Cell Biol. 2020; 12:322-5. doi: 10.1093/jmcb/mjaa014.

51. Deng L, LiC, Zeng Q, Liu X, Li X, Zhang H, et al. Arbidol combined with LPV/r versus LPV/r alone against Corona Virus Disease 2019: A retrospective cohort study. J Infect. 2020 Mar 11;S0163-4453(20)30113-4. doi: 101016/j. jinf.2020.03.002.

52. LiG, De Clercq E. Therapeutic options for the 2019 novel coronavirus (2019nCoV). Nat Rev Drug Discov . 2020 mar; 19(3):149-50. doi: 10.1038 / d41573-02000016-0.

53. Chang Y, Tung Y, Lee K, Chen T, Hsiao Y, Chang Hetal. potential therapeutic agents for COVID-19 based on the analysis of protease and RNA polymerase docking. Preprints 2020,2020020242. doi:10.20944/preprints202002.0242.v1.

54. Pizzorno A, Padey B, Julien T, Trouillet-Assant S, Traversier A, Errazuriz-Cerda E, et al. Characterization and treatment of SARS-CoV-2 in nasal and bronchial human airway epithelia. bioRxiv [Internet].2020 Available from https://www. biorxiv.org/content/10.1101/2020.03.31.017889v1. doi:10.1101/2020.03.31.017889.

55. Wang M, Cao R, Zhang L, Yang X, Liu J, Xu M, et al. Remdesivir and chloroquine effectively inhibit the recently emerged novel coronavirus (2019-nCoV) in vitro. Cell Res. 2020 Mar;30(3):269-71. doi: 10.1038/s41422-020-0282-0.

56. Wang Y,Zhang D, Du G, Du R, Zhao J, Jin Y, etal. Remdesivir in adults with severe COVID-19: a randomised, double-blind, placebo-controlled, multicentre trial. The Lancet. 2020;395:1569-78. doi:10.1016/S0140-6736(20)31022-9.
57. Grein J,OhmagariN Shin D,Diaz G, Asperges E Castagna A etal Compassionate Use of Remdesivir for Patients with Severe Covid-19. NEngl J Med. 2020;10:NEJMoa2007016. doi: 10.1056/NEJMoa2007016.

58. Becker RC. Covid-19 treatment update: follow the scientific evidence. J Thromb Thrombolysis. 2020 Apr 27;1-11. doi: 101007/s11239-020-02120-9.

59. Yao X, YeF,Zhang M, Cui C, Huang B, Niu P, et al. In vitro antiviral activity and projection of optimized dosing design of hydroxychloroquine for the treatment of Severe Acute Respiratory Syndrome Coronavirus 2(SARS-CoV-2). Clin Infect Dis. 2020 Mar 9;ciaa237. doi:101093/cid/ciaa237.

60. Liu J, Cao R, Xu M, Wang X, Zhang H, Hu H, etal. Hydroxychloroquine, aless toxic derivative of chloroquine, is effective in inhibiting SARS-CoV-2 infection in vitro. Cell Discov. 2020 Mar 18;6:16. doi: 10.1038/s41421-020-0156-0.

61. Chen Z, Hu J, Zhang Z, Jiang S, Han S, Yan D, et al. Efficacy of hydroxychloroquine in patients with COVID-19: results of a randomized clinical trial. medRxiv [Internet]. Available from: https://www.medrxiv.org/content/10.11 01/2020.03.22.20040758v3. doi: 10.1101/2020.03.22.20040758.

62. GautretP,Lagier J-C, ParolaP,Hoang VT, Meddeb L, Mailhe M, et al. Hydroxychloroquine and azithromycin as a treatment of COVID-19: results of an open-label non-randomized clinical trial. Int J Antimicrob Agents. 2020 Mar 20;105949. doi: 10.1016/j.jjantimicag.2020105949.

63. Geleris J, Sun Y,Platt J, Zucker J, Baldwin M, Hripcsak G, et al. Observational study of hydroxychloroquine in hospitalized patients with Covid-19. NEngl J Med. 2020;7:NEJMoa2012410. doi: 10.1056/NEJMoa2012410.

64. Mehra MR, DesaiSS, RuschitzkaF,Patel AN. Hydroxychloroquine or chloroquine with or without a macrolide for treatment of COVID-19:a multinational registry analysis [published online ahead of print, 2020 May 22] Lancet. 2020;S0140-6736(20)31180-6. doi:101016/S0140-6736(20)31180-6.

65. Fu B, XuX, WeiH. Why tocilizumab could be an effective treatment for severe COVID-19? J TransI Med. 2020 Apr 14;18(1):164. doi: 10.1186/s12967-020-023393.

66. Richardson P,Griffin I, Tucker C, SmithD, Oechsle 0, Phelan A, et al. Baricitinib as potential treatment for 2019-nCoV acute respiratory disease. Lancet. 2020 Feb 15;395(10223):e30-e31. doi:10.1016/S0140-6736(20)30304-4.

67. Cantini F,Niccoli L, Matarrese D, NicastriE, Stobbione P,Goletti D. Baricitinib therapy in COVID-19:A pilot study on safety and clinical impact [published online ahead of print, 2020 Apr 23]. J Infect. 2020;S0163-4453(20)30228-0. doi:10.1016/j.jinf.2020.04.017.

68. Qin C,Zhou L, Hu Z, Zhang S, Yang S, Tao Y, etal. Dysregulation of immune response in patients with COVID-19 in Wuhan, China. Clin. Clin InfectDis. 2020 Mar 12,ciaa248. doi:101093/cid/ciaa248.

69. Xu X, Han M, Li T, Sun W, Wang D, Fu B, et al. Effective treatment of severe COVID-19 patients with tocilizumab. Proc Natl Acad Sci U SA. 2020 May 19;117(20):10970-5. doi: 10.1073/pnas.2005615117.

70. Zhang X, Song K, Tong F, Fei M, Guo H, Zhaohui et al. First case of COVID-19 in a patient with multiple myeloma successfully treated with tocilizumab. Blood Adv.2020 Apr 14:4(7):1307-10. doi:10.1182/bloodadvances.2020001907.

71. Casadevall A, PirofskiL-A. The convalescent sera option for containing COVID-19. JClin Invest. 2020 Apr 1;130(4):1545-8. doi: 10.1172/JCl138003.

72. Duan K, Liu B, LiC, Zhang H, Yu T, Qu J, et al. Effectiveness of convalescent plasma therapy in severe COVID-19 patients. Proc Natl Acad SciUSA. 2020;117(17):9490-6. doi:101073/pnas.2004168117.

73. Shen C, Wang Z, Zhao F, Yang Y,Li J, Yuan J, et al. Treatment of 5 Critically IIIPatients with COVID-19 with Convalescent Plasma. JAMA. 2020 Mar 27;323(16):1582-9. doi: 10.1001/jama.2020.4783.

74. McKee M,Stuckler D. If the world fails to protect the economy, COVID-19 will damage health not just now but also in the future. Nat Med. 2020 May;26(5):640-2. doi:10.1038/s41591-020-0863-y. 
75. Fernandes N. Economic effects of coronavirus outbreak (COVID-19) on the world economy. Available at SSRN: https://ssrn.com/abstract03557504 or http://dx.doi.org/10.2139/ssrn.3557504. doi:10.2139/ssrn.3557504.

76. Verney S, Bosco A. Living parallel lives: Italy and Greece in an age of austerity. South European Society and Politics. JSouth Eur Soc Pol. 2013;18:397-426. doi: 10.1080/13608746.2014.883192

77. IfantiAA, Argyriou AA, Kalofonou FH, Kalofonos HP.Financial crisis and austerity measures in Greece: their impact on health promotion policies and public health care. Health Policy.2013;113(1-2):8-12. doi:10.1016/j. healthpol.2013.05.017.

78. McKibbin W, Fernando R. The global macroeconomic impacts of COVID-19: seven scenarios. CAMA Working Paper No. 19/2020. Available from: SSRN: https://ssrn.com/abstract03547729. doi: 10.2139/ssrn.3547729.

79. Rothstein MA, Talbott MK. Encouraging compliance with quarantine: a proposal to provide job security and income replacement. Am J Public Health. 2007 April; 97(Suppl 1):S49-S56. do: 10.2105/A.JPH.2006.097303.
80. Nicola M, AlsafiZ SohrabiC, Kerwan A, Al-Jabir A, losifidis C etal The socioeconomic implications of the coronavirus pandemic (COVID-19): A review [published online ahead of print, 2020 Apr 17]. IntJ Surg. 2020;78:185-93. doi:10.1016/j.j.ju.2020.04.018.

81. Recuero R, SoaresF. The disinformation discourse about COVID-19's cure on Twitter:A case study.JE-Compós. 2020. Epub. doi:10.1590/ SciELOPreprints.84.

82. UNHCR (United Nations High Commissioner for Refugees). Coronavirus outbreak [Internet]. [cited 2020 May 5]. Available from:https://www.unhcr. org/coronavirus-covid-19.html.

83. Kabir M, Afzal MS, Khan A, Ahmed H. COVID-19 pandemic and economic cost; impact on forcibly displaced people. Travel Med Infect Dis. 2020;101661. doi:10.1016/j.tmaid.2020.101661.

\section{Cristiane Yumi Koga-Ito}

\section{(Corresponding address)}

Department of Environmental Engineering and Oral Biopathology Graduate

Course, Institute of Science and Technology, São Paulo State University, UNESP. 